\title{
Revitalisasi Ruang Publik Kampung Luar Batang dengan Metode Hybrid Architecture
}

\author{
Adistria Dwirachmayanti dan Johanes Krisdianto \\ Departemen Arsitektur, Fakultas Arsitektur, Desain dan Perencanaan, Institut Teknologi Sepuluh Nopember (ITS) \\ e-mail: john_kris@arch.its.ac.id
}

\begin{abstract}
Abstrak-Kampung Luar Batang memiliki potensi wisata yang cukup besar dengan adanya Masjid dan Makam Luar Batang. Kegiatan wisata kampung tersebut memunculkan berbagai mata pencaharian dan pola hidup dari masyarakat Kampung Luar Batang yang mayoritas merupakan pewirausaha. Seluruh aspek tersebut memunculkan ide untuk merevitalisasi Kampung Luar Batang sebagai salah satu solusi menaikkan potensi wisata kampung dan tempat kegiatan masyarakat Kampung Luar Batang. Revitalisasi Kampung Luar Batang ini didasarkan pada pendekatan pada aspek sosiologi manusia didalamnya yang mempertimbangkan perilaku sosial di Kampung Luar Batang. Hal ini dilakukan dengan menggunakan metode desain Hybrid Architecture yaitu perpaduan dari aspek yang akan divitalkan pada Kampung Luar Batang dipadukan dengan ide modernisasi yang akan diusulkan untuk menunjang ide perancangan yang akan menunjang peningkatan kualitas tersebut. Revitalisasi Kampung Luar Batang ini akan mencakup perbaikan dan pengadaan kualitas ruang dari Kampung Luar Batang. Beberapa seperti pengadaan mix-use building, penataan ulang Kawasan Masjid Luar Batang, serta penataan ulang kawasan ruang usaha pewirausaha Kampung Luar Batang
\end{abstract}

Kata Kunci-Revitalisasi Kampung Luar Batang, potensi wisata, penataan ulang, Sosiologi, Hybrid Architecture.

\section{PENDAHULUAN}

K AMPUNG Luar Batang, Penjaringan, DKI Jakarta telah menjadi salah satu destinasi wisata dari dari 12 destinasi wisata pesisir Jakarta Utara yang telah ditetapkan oleh Pemerintah Provinsi DKI Jakarta [1]. Hal ini dikarenakan adanya sebuah situs bersejarah yang terdapat di Kampung Luar Batang, yaitu terdapat makam Sayid Husein, pemuka Agama Islam yang berdakwah di daerah pesisir Jawa,

Batavia dan Kota Surabaya di dalam sebuah kawasan Masjid Luar Batang. Masjid dan makam ini menjadi salah satu ruang publik ikon dari Kampung Luar Batang yang menjadi destinasi wisata religi umat muslim. Habib Sayid Husein Alaydrus adalah pemuka agama Kampung Luar Batang yang menjadi pelopor dari terbentuknya Kampung Luar Batang itu sendiri. Kawasan masjid ini menjadi landmark dari Kampung Luar Batang yang menimbulkan berbagai kegiatan ekonomi dan menjadi penunjang ekonomi warga setempat seperti masyarakat yang membuka usaha sendiri terutama dalam
Tabel 1.

Kegiatan dan Tempat berlangsungnya

\begin{tabular}{ccc}
\hline \hline No & Nama kegiatan & Tempat berlangsung \\
\hline 1 & $\begin{array}{c}\text { Ibadah Shalat, } \\
\text { Mengaji, Tausiah dsb }\end{array}$ & $\begin{array}{c}\text { Masjid Luar Batang } \\
\text { Makam Habib Husein } \\
\text { Alaydrus dan keluarga } \\
\text { (kawasan masjid) }\end{array}$ \\
2 & Ziarah Makam & $\begin{array}{c}\text { Aula Masjid Luar Batang } \\
\text { Yayasan TPA/TPQ }\end{array}$ \\
3 & Berkumpul warga & Kampung Luar Batang \\
4 & Pengajian warga & Koridor Masjid Luar \\
5 & Bermukim & Batang, area parkir Masjid \\
& Aktivitas Ekonomi ini) dan sepanjang \\
6 & Jalan Luar Batang \\
\hline \hline
\end{tabular}

Sumber: Hasil Observasi, 2017

Tabel 2.

Kegiatan Ekonomi dan Tempat berlangsungnya

\begin{tabular}{|c|c|c|c|}
\hline No & Nama Kegiatan & Tempat Kegiatan & Waktu Kegiatan \\
\hline 1 & $\begin{array}{l}\text { Penyewaan tempat } \\
\text { tinggal(kos-kosan) }\end{array}$ & Rumah warga Lantai 2 & Setiap Saat \\
\hline 2 & Wirausaha & $\begin{array}{c}\text { Sepanjang Jalan Luar } \\
\text { Batang dan Lantai } 1 \\
\text { rumah warga (ruko) } \\
\text { Area Parkir Masjid }\end{array}$ & $\begin{array}{l}\text { Setiap saat } \\
\text { (bergiliran) }\end{array}$ \\
\hline 3 & $\begin{array}{l}\text { Pasar Malam } \\
\text { Jum'at }\end{array}$ & $\begin{array}{l}\text { Luar Batang, Jl Luar } \\
\text { Batang I, Jl Luar } \\
\text { Batang II, Jl Luar } \\
\text { Batang V, Jl Luar } \\
\text { Batang VII }\end{array}$ & $\begin{array}{l}\text { Malam Jum'at } \\
(16.00-05.00) \text {. }\end{array}$ \\
\hline 4 & Pasar Pekan & $\begin{array}{l}\text { Area Parkir Masjid } \\
\text { Luar Batang, Jl Luar } \\
\text { Batang I, Jl Luar } \\
\text { Batang II, Jl Luar } \\
\text { Batang V, Jl Luar } \\
\text { Batang VII }\end{array}$ & $\begin{array}{l}\text { Pada Hari Raya } \\
\text { dan Hari Besar } \\
\text { Islam (09.00- } \\
\text { acara selesai) }\end{array}$ \\
\hline
\end{tabular}

Sumber: Hasil Observasi, 2017

bidang makanan di sekitar lokasi Masjid Luar Batang dan Makam Habib Husein (Tabel 1 dan Tabel 2) [2]. Selain itu, Masjid ini juga dijadikan tempat utama untuk tempat berkumpul warga Daya tarik tersebut tidak hanya Masjid Luar Batang,namun Museum Bahari dengan Menara Syahbandar, dan Pesisir Sunda Kelapa (Gambar 1) [3].

Berdasarkan informasi tersebut diatas, muncul sebuah ide untuk merevitalisasi ruang publik pada kawasan Masjid Luar Batang dan makam di Kampung Luar Batang, Penjaringan, Jakarta. Gagasan ini ditujukan untuk meredesain dan merehabilitasi ruang publik Kampung Luar Batang di daerah, rehabilitasi yaitu suatu langkah untuk melihat kembali sebuah 


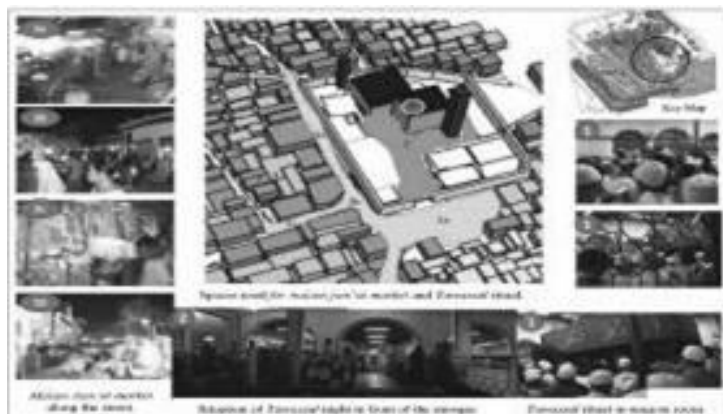

Gambar 1. Daerah yang menjadi Pasar Malam Jum'at .

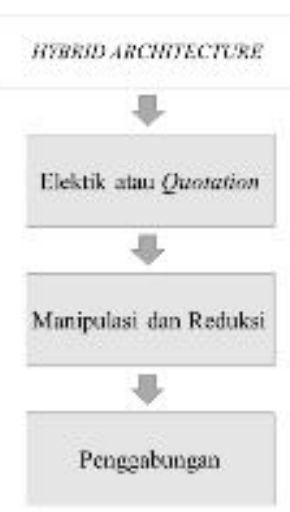

Gambar 2. Bagan Hybrid Architecture.

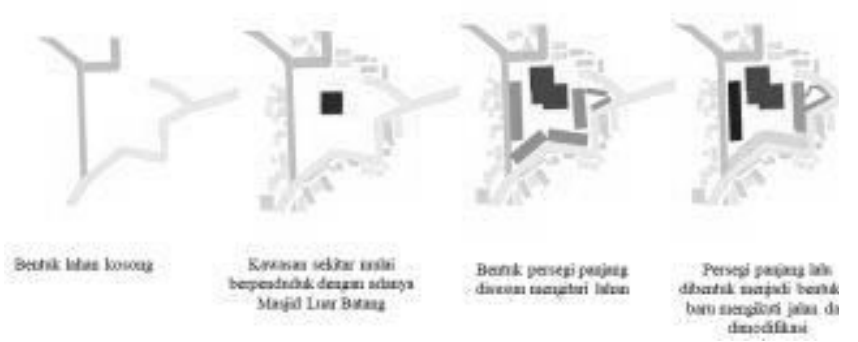

Gambar 3. Sirkulasi menuju Masjid Luar Batang.

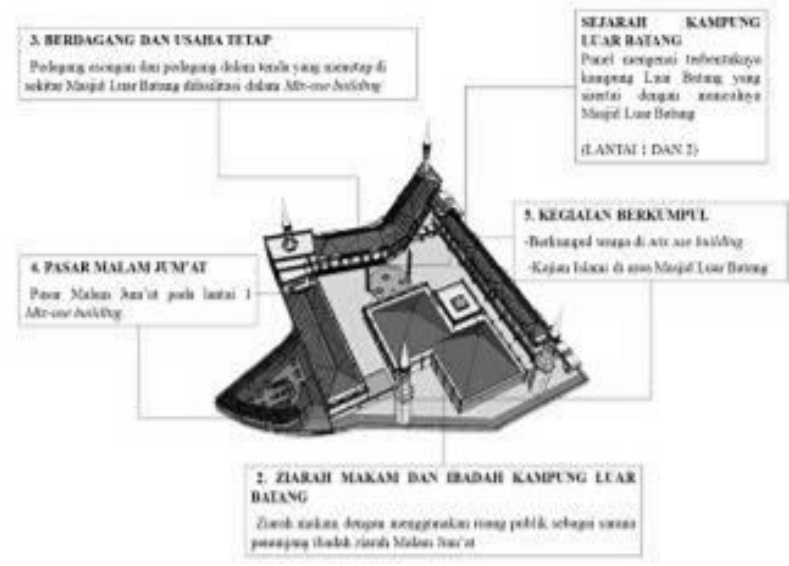

Gambar 4. Aspek vitalitas.

arsitektur yang sudah ada dan mennkonfigurasikan ulang lalu menata kembali lingkungan dan unsur didalamnya yang sudah ada sehingga sesuai dengan kebutuhan warga kampung sebagai penunjang kegiatan dan meningkatkan kualitas lingkungan yang akan berdampak pada berbagai macam sektor.

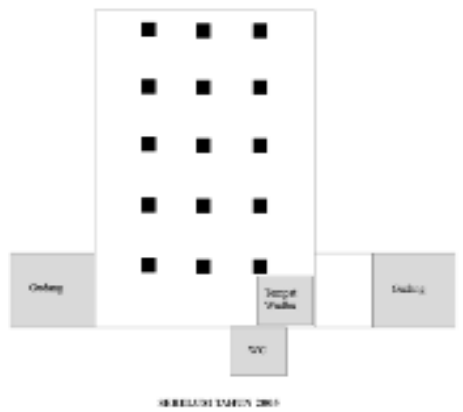

Gambar 5. Masjid Luar Batang pada awalnya (Hasil Observasi, 2017).
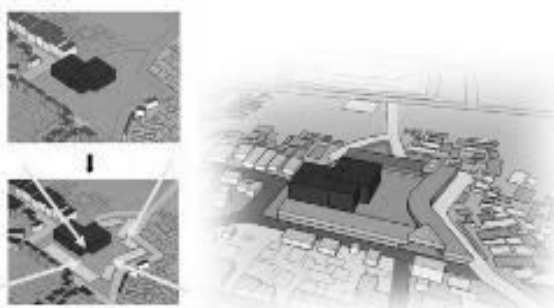

1
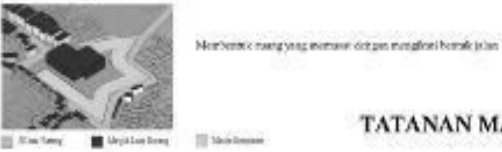

TATANAN MASSA

Gambar 6. Perkembangan Tatanan Massa.
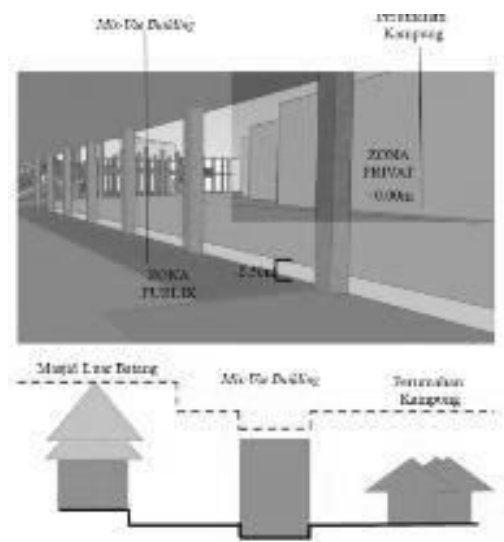

Gambar 7. Perbedaan Level Bangunan.
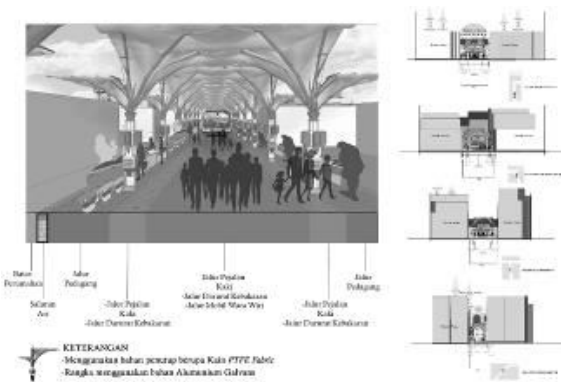

Gambar 8. Naungan Jalan Luar Batang.

\section{METODE PERENCANGAN}

Hybrid Architecture merupakan penggabungan beberapa aspek berbeda tentunya dalam ruang lingkup arsitektural. Hybrid merupakan hasil persilangan atau penggabungan dari 


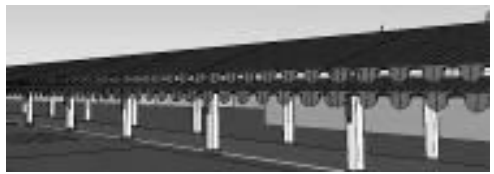

Gambar 9. Hasil Adaptasi Naungan dari Masjid Luar Batang.

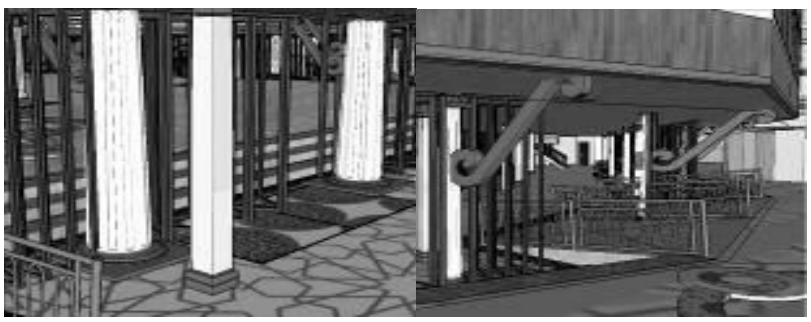

Gambar 10. Kolom dan Kantilever Mengadaptasi Pola Bentuk Struktur Masjid.

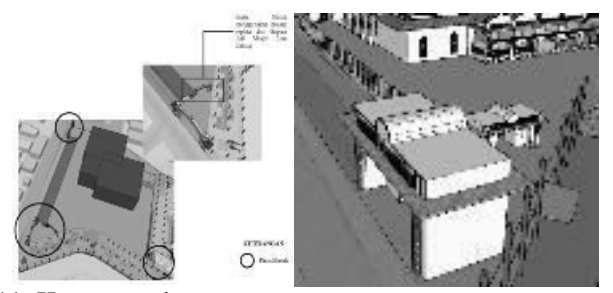

Gambar 11. Konsep gerbang.

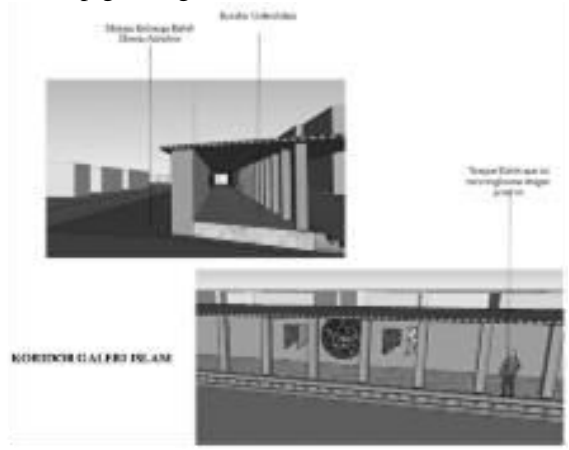

Gambar 12. Konsep Makam Luar Batang.

sesuatu yang berbeda. Penekanan pengertian hybrid ini adalah "hasil" dari persilangan atau penggabungan.

Konsep Hybrid Architecture merupakan salah satu metode perancangan dalam sebuah karya Arsitektur yang muncul di era Post Modern. Secara etimologis Hibrid merupakan penggabungan beberapa aspek yang berbeda (binari oposisi), tentunya dalam bidang Arsitektural. Berikut ini akan diuraikan pengertian Hibrid berdasarkan maknanya [4].

Perkawinan/keturunan dari dua jenis yang berbeda baik varitas, ras atau spesis yang berbeda. Dalam analisa bahwa perbedaan varitas bisa saja masih menjadi satu spesis, perbedaan ras bisa saja masih dalam satu spesis sebaliknya beda spesies bisa saja masih dalam satu ras dan varitas [4] perbedaan atau hasil persilangan antara sesuatu yang berbeda dengan adanya dominasi dari salah satu kutub yang berbeda [4].

Metode ini memiliki beberapa langkah pengerjaan yaitu:

\section{A. Elektik atau Quotation}

Elektik atau Quotation memiliki arti menelusuri dan

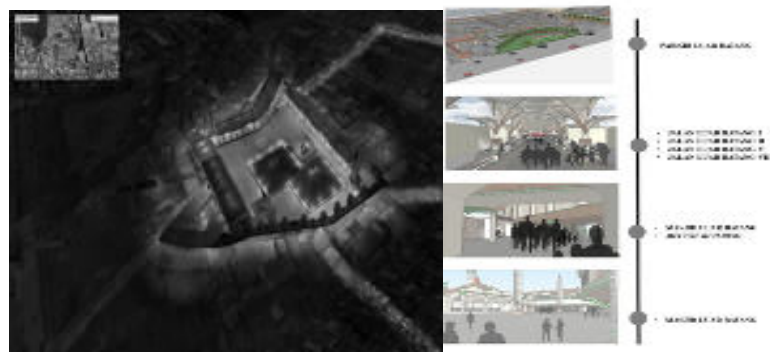

Gambar 13. Urutan Perjalanan dan Perspektif.

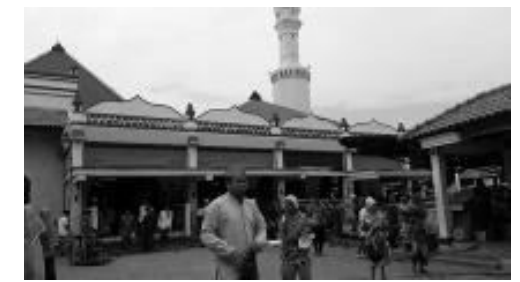

Gambar 14. Plaza Masjid sebagai ruang luar yang diberdayakan.

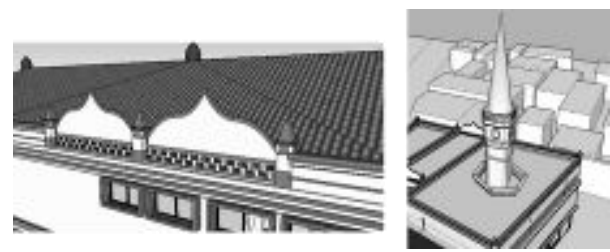

Gambar 15. Plaza Masjid sebagai ruang luar yang diberdayakan.

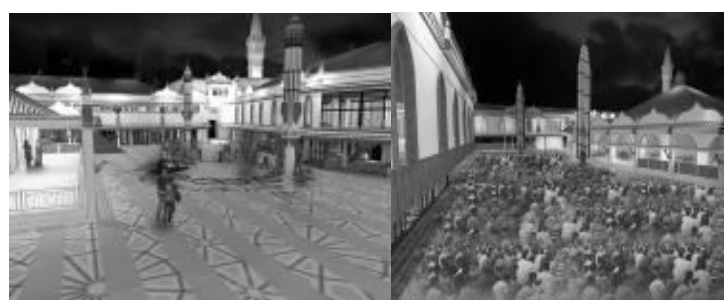

Gambar 16. Plaza Masjid sebagai ruang luar yang diberdayakan.

memilih pembendaharaan bentuk dan elemen arsitektur dari masa lalu yang dianggap potensial untuk diangkat kembali. Asumsi dasarnya adalah telah mapannya kode dan makna yang diterima dan dipahami oleh masyarakat

\section{B. Manipulasi dan Reduksi}

Elemen-elemen elektik atau hasil dari quotation tersebut selanjutnya dimanipulasi atau dimodifikasi dengan caracara yang dapat menggeser, mengubah, dan atau memutarbalikanmakna yang telah ada. Beberapa teknik manipulasi ini meliputi:

1. Reduksi. Reduksi adalah pengurangan bagian-bagian yang dianggap tidak penting.

2. Simplifikasi adalah penyederhanaan bentuk dengan cara membuang bagian-bagian yang dianggap tidak atau kurang penting.

3. Repetisi. Repetisi artinya pengulangan elemenelemen yang di-quotation-kan, sesuatu yang tidak ada pada referensi. 


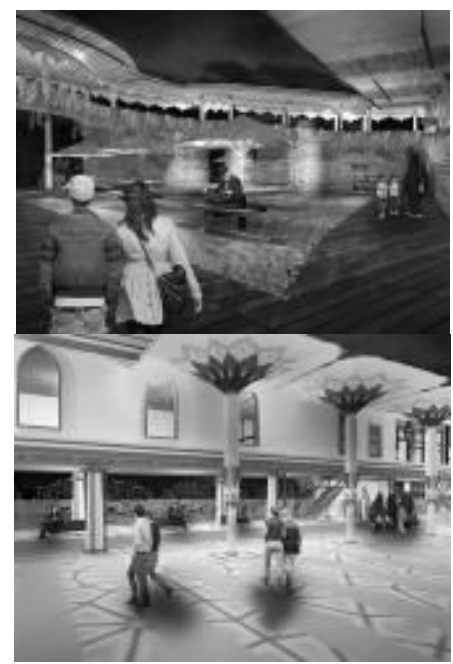

Gambar 17. Taman Allah dan koridor makam.

4. Distorsi bentuk. Perubahan bentuk dari bentuk asalnya dengan cara misalnya dipuntir (rotasi), ditekuk, dicembungkan, dicekungkan dan diganti bentuk geometrinya.

5. Disorientasi. Perubahan arah (orientasi) suatu elemen dari pola atau tatanan asalnya.

6. Disporsisi. Perubahan proporsi tidak mengikuti sistem proporsi referensi (model).

7. Dislokasi. Perubahan letak atau posisi elemen di dalam model referensi sehingga menjadi tidak pada posisinya seperti model referensi.

\section{Penggabungan}

Penggabungan dan penyatuan beberapa elemen yang telah dimanipulasi atau dimodifikasi ke dalam desain yang telah ditetapkan order-nya (gambar 2).

\section{HASIL DAN EKSPLORASI}

Revitalisasi ruang publik Kampung Luar Batang berdasarkan pada aspek vitalitas yang diangkat yaitu:

1. Sejarah Kampung Luar Batang

2. Ziarah Makam dan Ibadah Kampung Luar Batang

3. Berdagang dan Usaha Tetap

4. Pasar Malam Jumat

5. Kegiatan berkupul

Berikut adalah tahapan aspek vitalitas yang dingkat tersebut digabungkan dengan hasil metode Hybrid Architecture:

\section{A. Tahap Elektrik atau Quotation}

1. Langgam Masjid Luar Batang yaitu Masjid Hindu dan Jawa

2. Gerbang Masjid

3. Soko Guru/ Tiang berbentuk segi 4

4. Warna Masjid
5. Lantai kayu dan ubin menjadi dari keramik dan batu granit (saat ini)

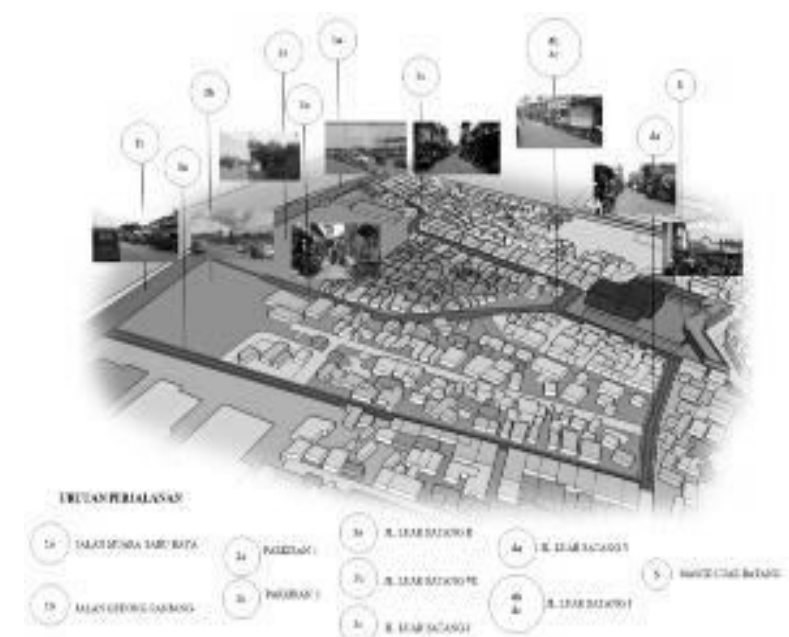

Gambar 18. Sirkulasi menuju Masjid Luar Batang.

6. Tiang kayu menjadi tiang beton pengambilan dari Masjid

7. Penggunaan gigi balang

8. Atap Masjid

9. Fasilitas penunjang Masjid

B. Manipulasi dan Reduksi

1. Kolom Mix-use menggunakan bentuk soko guru Masjid

2. Perbedaan zona dengan perbedaan material lantai

3. Gerbang Masjid sebagai Pintu Masuk utama dengan penambahan pintu masuk dengan memanipulasi gerbang tersebut

4. Penggunaan gigi balang dan timpa laju pada konsep naungan

5. Naungan pedagang di sepanjang Jalan Luar Batang

6. Naungan parkir dengan tambahan unsur betawi dan atap masjid

7. Perletakkan tempat wudhu diubah

8. Pemakaman keluarga yang dimodifikasi menjadi galeri

9. Tatanan Mix use building berdasarkan Masjid Luar Batang

C. Penggabungan

1. Ruang penunjang Masjid (kantor sekretariat, yayasan dsb) menjadi satu kesatuan dengan mix-use building

2. Tenda usaha pada parkiran menjadi satu kesatuan dengan mix-use building

3. Penyamaan langgam mix-use building dengan Masjid Luar Batang yaitu penggunaan atap,warna dll.

\section{Penerapan Metode Dalam Desain}

1. Tatanan Massa Menerapkan beberapa teknik manipulasi meliputi Reduksi, Simplifikasi. Repetisi, 
Distorsi, Disorientasi, Disporsisi, Dislokasi (Gambar 5,6 dan 7).

2. Simplikasi: Mengambil bentuk dasar persegi panjang dari bentuk surau yang terdri dari beberapa persegi panjang yang disus

3. Repetisi: pengulangan bentuk persegi panjang yang mengelilingi area lahan sehingga memusat di tengah

4. Distorsi, disorientasi dan disposisi: Bentuk persegi panjang yang diletakkan mengelilingi lahan lalu ditumpulkan mengikuti bentuk jalan sekitar sehingga orientasi bangunan memusat pada masjid dan tidak lagi mengikuti proporsi masjid

5. Dislokasi: Penempatan massa mix-use building tidak setara dengan Masjid Luar Batang, dengan mempertimbangkan tingkatan kasta dari masjid yang lebih tinggi

\section{E. Citra Kawasan Sekitar}

Berdasarkan beberapa aspek diatas, sejalan dengan ide untuk memperbaiki sirkulasi menuju Kawasan Masjid Luar Batang dengan memberikan naungan (gambar 8). Naungan yang dikonsepkan menggunakan langgam dari adaptasi Masjid Luar Batang yang dikombinasikan dengan unsur Betawi yaitu penggunaan Gigi Balang sebagai hiasan saja (gambar 9). Hal ini ditujukan sebagai pelengkap dari langgam Masjid Luar Batang yang dikembangkan dengan konsep lokal dari budaya DKI Jakarta yaitu Suku Betawi.

\section{Citra Kawasan Masjid Luar Batang}

Citra Mix-use building terinspirasi dari langgam yang ada pada Masjid Luar Batang. Mix-use building mengadaptasi detail, warna bentukan yang dimodifikasi seperti tatanan massa yang telah dibahas sebelumnya (gambar 10).

Masjid Luar Batang itu sendiri memiliki beberapa bagian yang dianggap vital sebagai cagar budaya yang tidak boleh dirubah maupun dihilangkan keberadaannya. Bagian vital tersebut adalah Gerbang Masjid Luar Batang, Bagian Masjid itu sendiri serta Makam Habib Husein Alaydrus dan keluarga. Berdasarkan dari hal tersebut maka konsep dari gerbang masjid ini mengadaptasi dari gerbang yang ada dengan mengalami repetisi dengan tidak menghilangkan gerbang yang telah ada sebelumnya (Gambar 11).

Penggunaan pola bentuk masjid diadaptasi menjadi elemen penghias. Minaret yang ada pada sisi masjid dijadikan sebagai elemen mix-use building, hal ini berdasarkan pada desain masjid yang belum terseleselesaikan (berdasarkan keputusan Gubernur DKI Jakarta terpilih saat itu Fauzi Bowo) untuk membuat 4 minaret sehingga menjadikan mix-use building menyatu dengan Masjid Luar Batang (Gambar 15)

Pada peningkatan kualitas area Masjid Luar Batang dan mix-use building, sebagai bentuk dari pengembangan proses elektrik Hybrid Architecture, dilakukan pemberdayaan ruang publik (perubahan area parkir, lahan kosong dan plaza eksisting) menjadi area baru yaitu pemberdayaan Plaza Masjid dan Taman Allah. Plaza masjid (Gambar 16) digunakan sebagai sarana penunjang dari Masjid Luar Batang disertai pertunjukan islami (marawis) yang digunakan pada setiap malam Jum'at. Area ini juga dapat digunakan untuk bersantai dan kegiatan lainnya. Prasarana penunjang dari plaza masjid adalah payung yang dapat terbuka dan tertutup sesuai dengan kebutuhan pengguna (Gambar 17).

\section{Sirkulasi}

Sirkulasi utama menuju Masjid Luar Batang adalah Jl Luar Batang I. Jl Luar Batang II, Jl Luar Batang V dan Jl. Luar Batang VII. Hal ini dikarenakan mayoritas kegiatan ekonomi terjadi pada jalan-jalan tersebut sehingga area ini menjadi salah satu bagian terdesain sebagai wadah dari kegiatan ekonomi yang menjadi salah satu aspek vitalitas Kampung Luar Batang serta perbaikan kualitas lingkungan.

\section{KESIMPULAN}

Kampung Luar Batang saat adalah salah satu destinasi wisata religi yang menjadi tujuan wisatawan DKI Jakarta. Hal ini dikarenakan terdapat Masjid Luar Batang dan Makam Keramat Habib Husein Alaydrus beserta dengan keluarganya. Adanya ikon ini menjadikan area Kampung Luar Batang selalu ramai oleh wisatawan hampir pada setiap harinya. Kesempatan ini digunakan warga untuk membuka wirausaha disepanjang jalur wisatawan lewati hingga area Masjid Luar Batang. Tidak hanya hal tersebut, ruang publik Masjid Luar Batang juga memiliki $42 \%$ tempat yang digunakan sebagai kegiatan warga setempat.

Dengan ini Metode Hybrid Architecure pada revitalisai ruang publik Kampung Luar Batang ditujukan sebagai bagian dari mengangkat vitalitas ruang publik Kampung Luar Batang yang dikembangkan dan menjadi lebih baik dengan penggabungan unsur modernisasi sesuai dengan kebutuhan area setempat.

\section{DAFTAR PUSTAKA}

[1] T. M. S. Kasman, "Hubungan Karakteristik Penduduk dengan Pemilihan Ruang Publik di Kampung Luar Batang, Jakarta Utara," Institut Teknologi Bandung, 2016.

[2] Ashadi and et al, "Fungsi Masjid Bersejarah Luar Batang, Jakarta Utara, Dan Pengaruhnya Terhadap Pola Permukiman Di Sekitarnya," Universitas Muhammadiyah Jakarta, 2017.

[3] H. Iskandaria, "Peran Kampung Luar Batang, Kecamatan Penjaringan Jakarta Utara dalam Menunjang Konservasi Kota Tua,” Institut Teknologi Sepuluh Nopember Surabaya, 2009.

[4] D. E. Ningsar, "Komparasi Konsep Arsitektur Hibrid dan Arsitektur Simbiosis," Manado, 2012. 